\title{
HUBUNGAN BMI DENGAN KADAR GULA DARAH PADA WANITA DEWASA DI DESA CIHANJUANG RAHAYU
}

\author{
Okno Riris $^{1 *}$, Yunus Elon ${ }^{2}$ \\ ${ }^{1,2}$ Fakultas Keperawatan, Universitas Advent Indonesia \\ E-mail: oknoriris@gmail.com
}

\begin{abstract}
Portrays of Body Mass Index (BMI) determine the ideal_weight body index of people. The increase in BMI is one indicator in determining a person's health status. The high BMI indicate are overweight or obese and are at risk of suffering from hypertension, type 2 diabetes, heart disease, stroke, cholesterol and cancer. Obesity can increase blood sugar levels. The purpose of this study was to determine the relationship between BMI and fasting blood sugar levels in adult women. This research used a cross sectional study, which is an analytical observational study of 45 adult female respondents with an age limit of 26-45 years. The results of the bivariate analysis showed that subject with the age of 36-45 years was 53.3\%, subject with age of 26-35 years is 46.7\%; average of elementary school education $=44.4 \%$. SMP 44.4\% and SMA $11.1 \%$. BMI above normal is $73.3 \%$ and norm is $26.7 \%$. Whereas blood sugar was $91.1 \%$ normal, and 4.4\% was high and 4.4\% was low. The results of the Pearson Product-Moment Correlation .023 univariate analysis with $p$-value $=>.05$. The results of the analysis of this study showed that there was no significant relationship between BMI and fasting blood sugar levels in adult women. To get a comprehensive picture, further research on the relationship of BMI with fasting blood sugar levels needs to be done in various age groups, and involves both sexes.
\end{abstract}

Kata Kunci: Body Mass Index, Obesity, Fasting Blood Sugar Levels

\begin{abstract}
Abstrak
Body Mass Index (BMI) merupakan gambaran untuk menentukan keidealan berat badan seseorang. Peningkatan BMI menjadi salah satu indikator dalam menentukan status kesehatan seseorang. BMI yang tinggi menunjukkan kelebihan berat badan atau obesitas dan beresiko menderita hypertensi, diabetes meletus type 2, jantung, stroke, kolesterol dan kanker. Obesitas dapat mengakibatkan meningkatnya kadar gula darah. Tujuan penelitian ini adalah menentukan hubungan BMI dengan kadar gula darah puasa pada wanita dewasa. Jenis penelitian ini menggunakan Cross sectional study, yang merupakan penelitian observasional yang bersifat analitik terhadap 45 responden wanita dewasa dengan batasan umur 26-45 tahun. Hasil analisis bivariate menunjukkan usia 36-45 tahun sebesar 53,3\%, 26-35 tahun 46,7\%; rata-rata pendidikan $\mathrm{SD}=44,4 \%$. SMP 44,4\% dan SMA $11,1 \%$. BMI diatas normal sebanyak $73.3 \%$ dan normal 26,7\%. Sedangkan gula darah 91,1\% normal, dan 4,4\% tinggi serta 4,4\% rendah. Hasil analisis univariate Pearson Product-Moment Correlation .023 dengan $p$-value $=>.05$. Hasil analisa penelitian ini menunjukan bahwa tidak ada hubungan yang bermakna antara BMI terhadap kadar gula darah puasa pada wanita dewasa. Untuk mendapatkan gambaran yang menyeluruh maka, penelitian selanjutnya tentang hubungan BMI dengan kadar gula darah puasa perlu dilakukan pada berbagai kelompok usia, serta melibatkan kedua jenis kelamin.
\end{abstract}

Kata Kunci: Indeks Massa Tubuh, Obesitas, Kadar Gula Darah Puasa

\section{Pendahuluan}

Body Mass Index (BMI) merupakan hasil dari rasio perbandingan tinggi badan dan berat badan seseorang yang dapat digunakan untuk melihat tingkat keidealan massa tubuh seseorang. Hasil perhitungan BMI dapat membantu menilai status kesehatan seseorang, terhadap resiko penyakit akibat kekurangan atau kelebihan berat badan. Seseorang dengan BMI diatas normal disebut obesitas. Dimana kondisi tersebut terjadi akibat penumpukan jaringan lemak yang berlebih dalam tubuh. (Roby Arismunandar,Tahun 2015).

Menurut WHO (2012) obesitas merupakan masalah epidemic di dunia. Prevalensi obesitas di negara maju dan negara berkembang mengalami peningkatan setiap tahunnya. Seperti Pada tahun 2008 mengalami peningkatan dua kali lipat dibandingkan pada tahun 1980. Pada Tahun 2008 terdapat $14 \%$ 
wanita dewasa yang mengalami obesitas dan $10 \%$ pria dewasa yang mengalami obesitas. dibandingkan pada tahun 1980 hanya $8 \%$ wanita dewasa yang mengalami obesitas dan $5 \%$ pria dewasa yang mengalami obesitas didunia.

Di indonesia sendiri prevalensi obesitas pada orang dewasa setiap tahunnya mengalami peningkatan menurut RISKESDAS (2018) terdapat 10,5\% yang mengalami obesitas pada tahun 2007 dan 14,8 pada Tahun 2013, sedangkan pada tahun 2018 terdapat $21,8 \%$ yang mengalami obesitas. Sementara Prevalensi berdasarkan provinsi di Indonesia yang mengalami obesitas pada orang dewasa tertinggi di Sulawesi Utara (30,2\%), yang kedua yaitu DKI Jakarta $(29,8 \%)$,yang ketiga yaitu Kalimantan Timur (28,7\%), dan Jawa Barat dalam urutan ke-14.

Menurut HISOBI (Himpunan Studi Obesitas Indonesia) Tahun 2004 ditemukan bahwa jumlah obesitas pada wanita dewasa lebih banyak dibandingkan pada pria dewasa. Persentasenya adalah 11,02 \% (wanita dewasa) dan 9,16\% (Pria dewasa). Menurut Malinti dan Elon (2019) obesitas pada pria dewasa juga mengalami tren peningkatan. Dengan persentasi $12 \%$ overweight dan $24 \%$ obesitas atau $36 \%$ dengan berat badan diatas normal. Dan bergeser dari usia diatas 30 tahun ke usia dibawah 30 tahun.

Menurut data diatas obesitas yang terus meningkat tiap tahunnya baik di dunia, maupun di negara kita sendiri Indonesia hingga provinsi menjadi sesuatu yang mengkhawatirkan karena efek dari obesitas dapat menyebabkan meningkatnya resiko penyakit degeneratif antara lain; diabetes melitus tipe 2, hipertensi, jantung koroner, dislipidemia, osteoporosis, dan penyakit kardiovaskuler lainnya.

Hingga saat ini penyakit degeneratif telah menjadi penyebab kematian terbesar di dunia. Hampir 17 juta orang meninggal lebih awal setiap tahun akibat epidemic global penyakit degeneratif (WHO Tahun 2012).

Selain itu penderita obesitas memiliki resiko tinggi terjadinya resistensi insulin, menurut teori Guyton tahun 2007 obesitas dapat mengakibatkan meningkatnya kadar gula darah. Kadar gula darah merupakan istilah yang mengacu pada kadar atau banyaknya kandungan gula didalam sirkulasi darah dalam tubuh. kandungan gula yang tinggi dalam sirkulasi darah dapat membuat gula tersebut tidak bisa di metabolisme dengan baik oleh sel dan akibatnya terjadi peningkatan glukosa dalam darah. Gula yang ada didalam darah disebut sebagai glukosa,yakni bentuk gula yang paling sederhana. Kadar glukosa dalam darah umumnya saat puasa selama 8 jam dalam ukuran 60-100 $\mathrm{mg} / \mathrm{dL}$.

Oleh karena itu pentingnya untuk menjaga berat badan dalam batas normal, agar tidak sampai obesitas perlu dilakukan modifikasi pola makan dan aktivitas fisik dengan cara mengontrol porsi makan dan jenis makanan yang dikonsumsi dan untuk menurunkan berat badan dengan cara melakukan aktivitas fisik atau olahraga. Olahraga yang dianjurkan adalah jalan kaki selama 30 menit, dengan frekuensi 5-6 kali/Minggu karena dapat membakar kadar lemak dalam tubuh dan dapat meningkatkan massa otot tubuh.

Berdasarkan data diatas bahwa BMI diatas normal (Obesitas) memiliki hubungan dalam peningkatan kadar gula darah dan berdasarkan data diatas dapat ditemukan setiap tahunnya yang mengalami obesitas terus meningkat, oleh karena itu peneliti ingin membuktikan teori yang sudah ada dan peneliti ingin meneliti "Hubungan BMI dengan kadar gula darah pada wanita dewasa di Rw 12 Desa Cihanjuang Rahayu".

\section{Metodologi Penelitian}

Jenis penelitian ini menggunakan Cross sectional study, yang merupakan penelitian observasional yang bersifat analitik. Penelitian ini menggunakan teknik purposive sampling. Penelitian ini dilakukan bulan September 2019 di RW 12 Desa Cihanjuang Rahayu, Kab. Bandung Barat.

Populasi dalam penelitian ini adalah wanita dewasa dengan batasan umur 26-45 tahun. berdasarkan total populasi wanita dewasa yang memenuhi kriteria pengambilan sample dilakukan dengan cara Simple Randome Sampling, didapatkan jumlah sampel sebanyak 45 responden. Sampel dalam penelitian ini memiliki kriteria inklusi yang ditetapkan adalah sehat jasmani, tidak mempunyai riwayat diabetes (belum pernah terdiagnosa diabetes oleh tenaga kesehatan) sedangkan kriteria ekslusi yang ditetapkan dalam penelitian ini adalah gangguan mental, wanita dewasa yang sedang hamil, wanita dewasa sedang menyusui, dan wanita dewasa yang sedang mengonsumsi obatobatan yang dapat menurunkan atau meningkatkan kadar gula darah.

Komisi Etik Penelitian Kesehatan Universitas Advent Indonesia telah memberikan surat keputusan layak etik pada penelitian ini dimana surat tersebut dikeluarkan pada tanggal 12 September 2019 dengan NO.17/KEPK-FIK.UNAI/EC/VIII/19. Adapun cara pengambilan sampel dilakukan dengan membawa surat izin dari puskesmas dan diberikan kepada ketua RW dan RT setelah itu mencari respoden ke rumah-rumah, teknik pengambilan data menggunakan teknik wawancara dan apabila responden sesuai dengan kriteria inklusi dan bersedia maka akan dijelaskan tujuan penelitian dan membuat kontrak waktu, dan seluruh responden di berikan informasi untuk puasa pada malam hari selama 8-10 jam dimulai pada jam 22.00 - 08.00 keesokan pada pagi harinya dikumpulkan di aula SMK Perjuangan, Parongpong, Kabupaten Bandung Barat, untuk pengambilan darah. Sebelum dilakukan pengambilan darah responden akan ditimbang berat badannya terlebih dahulu menggunakan timbangan berat badan digital yang terkalibrasi dengan tingkat ketelitian $0,1 \mathrm{~kg}$, diukur tinggi badannya menggunakan microtoise stature meter dengan tingkat ketelitian $0,1 \mathrm{~cm}$. Hasil dari berat badan dan tinggi badan dapat menentukan Body Mass Index responden, 
adapun kategori klasifikasi Body Mass Index sebagai berikut :

Tabel 1. Kategori Body Mass Index (BMI)

\begin{tabular}{cc}
\hline Kategori & Rentang \\
\hline Underweight & $<18,5$ \\
Normal & $18,5-24,9$ \\
Overweight & $25-29,9$ \\
Obesitas & $\geq 30$ \\
\hline
\end{tabular}

World Health Organization, 2016

Setelah itu responden akan mengisi lembar persetujuan Informed Consent dan questioner mengenai kebiasaan makan serta aktivitas fisik setelah itu responden akan diambil darahnya untuk dianalisis di Laboratorium Rumah Sakit Jiwa dan proses pengambilan sampel darah dilakukan oleh petugas profesional dari Rumah Sakit Jiwa Bandung. Hasil dari pengecekan Gula darah puasa diklasifikasikan dengan menggunakan standar sebagai berikut :

Tabel 2. Batasan Nilai Gula Darah Puasa

\begin{tabular}{ccc}
\hline Kadar & Rentang & Kategori \\
\hline Gula Darah & $<80 \mathrm{mg} / \mathrm{dL}$ & Rendah \\
Puasa & $80-100 \mathrm{mg} / \mathrm{dL}$ & Normal \\
& $\geq 126 \mathrm{mg} / \mathrm{dL}$ & Tinggi \\
\hline
\end{tabular}

Perkeni (2006)

Dalam penelitian ini terdiri dari Variabel independen yaitu BMI (Body Mass Index) dan Variabel dependen yaitu kadar gula darah. Analisis data menggunakan software SPSS 20.0, analisis deskriptif digunakan untuk mengetahaui informasi gambaran usia, status pernikahan, tingkat pendidikan, BMI, kadar gula darah dan Analisa statistika uji Pearson hubungan BMI dengan kadar Gula darah. Hasil analisis menunjukan data berdistribusi normal sehingga uji korelasi menggunakan Pearson Product-Moment Correlation yang digunakan untuk mengetahui hubungan antara Body Mass Index dengan kadar gula darah puasa yang nilai $\mathrm{p}<0.05$ terdapat korelasi yang bermakna antara dua variabel.

\section{Hasil}

Hasil analisis univariate dalam penelitian ini terdiri dari Frekuensi usia, Frekuensi status pernikahan, Frekuensi tingkat pendidikan, BMI, dan gula darah puasa. Seperti terlihat pada table 3,4,5,6 dan 7. Dan analisis bivariate untuk melihat hubungan antara BMI dengan kadar gula darah puasa pada wanita dewasa ditunjukkna pada table 8 .
Tabel 3. Distribusi frekuensi responden berdasarkan usia

\begin{tabular}{ccc}
\hline Klasifikasi & Frekuensi & Persentasi \\
\hline Dewasa Muda & 21 Responden & $46,7 \%$ \\
(26-35 Tahun) & & \\
Dewasa Tua & 24 Responden & $53,3 \%$ \\
(36-45 Tahun) & & \\
\hline
\end{tabular}

Tabel 3 menunjukan jumlah respondent sebanyak 45 repondent, dan mayoritas respondent yang mengikuti penelitian ini masuk dalam kategori dewasa tua dengan rentang usia 36-45 tahun sebanyak 24 respondent $(53,3 \%)$, sedangkan respondent dewasa muda sebanyak 21 respondent dengan rentang usia 2635 tahun $(46,7 \%)$.

Tabel 4. Distribusi frekuensi responden berdasarkan Status pernikahan

\begin{tabular}{ccc}
\hline Klasifikasi & Frekuensi & Persentasi \\
\hline Menikah & 34 Responden & $75,6 \%$ \\
Janda & 9 Responden & $20 \%$ \\
Berpisah & 2 Responden & $4,4 \%$ \\
\hline
\end{tabular}

Tabel 4 memberikan gambaran tentang status pernikahan, dimana mayoritas status pernikahan respondent yang mengikuti penelitian ini dalam kategori sudah menikah sebanyak 34 responden $(75,6 \%)$, sedangkan yang berstatus janda sebanyak 9 responden dengan persentase $(20 \%)$, dan yang berstatus berpisah sebanyak 2 responden $(4,4 \%)$.

Tabel 5. Distribusi frekuensi responden berdasarkan Tingkat pendidikan

\begin{tabular}{ccc}
\hline Klasifikasi & Frekuensi & Persentasi \\
\hline SD & 20 Responden & $44,4 \%$ \\
SMP & 20 Responden & $44,4 \%$ \\
SMA & 5 Responden & $11,1 \%$ \\
\hline
\end{tabular}

Tabel 5 menunjukkan distribusi responden berdasarkan tingkat pendidikan, mayoritas pendidikan akhir respondent yang mengikuti penelitian ini sebanyak 20 respondent $(44,4 \%) \mathrm{SD}, 22$ responden (44,4\%) SMP dan 5 respondent atau $11,1 \%$ lulusan SMA. 
Tabel 6. Distribusi frekuensi responden berdasarkan BMI

\begin{tabular}{ccc}
\hline Klasifikasi & Frekuensi & Persentasi \\
\hline Normal & 12 Responden & 26,7\% \\
Gemuk & 19 Responden & $42,2 \%$ \\
Obesitas & 14 Responden & $31,1 \%$ \\
\hline
\end{tabular}

Tabel 6 memperlihatkan karakteristik responden berdasarkan BMI. mayoritas respondent yang mengikuti penelitian ini masuk dalam kategori BMI Gemuk sebanyak 19 respondent dengan persentase $(42,2 \%)$, sedangkan yang termasuk dalam kategori BMI obesitas sebanyak 14 responden dengan persentase $(31,1 \%)$, dan yang termasuk dalam kategori BMI normal sebanyak 12 responden dengan persentase (26,7\%). BMI obesitas sebanyak 14 responden dengan persentase $(31,1 \%)$, dan yang termasuk dalam kategori BMI normal sebanyak 12 responden dengan persentase $(26,7 \%)$.
Tabel 7. Distribusi frekuensi responden berdasarkan kadar Gula darah puasa

\begin{tabular}{ccc}
\hline Klasifikasi & Frekuensi & Persentase \\
\hline Rendah & 2 Responden & $4,4 \%$ \\
Normal & 41 Responden & $91,1 \%$ \\
Tinggi & 2 Responden & $4,4 \%$ \\
\hline
\end{tabular}

Tabel 7 menunjukkan mayoritas responden yang mengikuti penelitian ini masuk dalam kategori kadar gula darah puasanya dalam batas normal sebanyak 41 responden dengan persentase $(91,1 \%)$, sedangkan yang termasuk dalam kategori gula darahnya dalam batas rendah sebanyak 2 responden dengan persentase $(4,4 \%)$, dan yang termasuk dalam kategori gula darahnya dalam batas tinggi sebanyak 2 responden dengan persentase $(4,4 \%)$.

Tabel 8. Analisa Uji Pearson Moment Product Hubungan BMI dengan kadar Gula darah puasa

\begin{tabular}{ccccc}
\hline Variabel & Mean & Std. Deviasi & $r$ & $\begin{array}{c}\text { Sig. } \\
(\mathbf{2} \text {-tail })\end{array}$ \\
\hline BMI & 28.4547 & 4.57632 & .023 & .883 \\
Gula Darah Puasa & 99.7333 & 39.96385 & & \\
\hline$\alpha=<.005$ & & &
\end{tabular}

\section{Pembahasan}

Berdasarkan hasil penelitian yang di lakukan pada 45 responden ditemukan mayoritas wanita dewasa tua dengan usia 36-45 tahun sebanyak 24 responden dengan persentase $(53,3 \%)$. Umumnya manusia mengalami perubahan fisiologi yang secara drastis menurun dengan cepat setelah usia 40 tahun. Teori yang ada mengatakan bahwa seseorang $\geq 45$ tahun memiliki peningkatan resiko terhadap terjadinya DM dan intoleransi glukosa yang di sebabkan oleh faktor degeneratif yaitu menurunya fungsi tubuh, khususnya kemampuan dari sel $\beta$ dalam memproduksi insulin untuk memetabolisme glukosa dalam darah. kejadian obesitas meningkat seiring dengan meningkatkannya umur seseorang yang diakibatkan karena penumpukan lemak dalam tubuh, terutama lemak pada perut. Hal ini sesuai dengan hasil penelitian yang dilakukan oleh Christina, D., dan Sartika, AD., (2011) yang menemukan bahwa responden yang berusia $>40$ tahun memiliki resiko terjadinya obesitas lebih besar dibandingkan dengan responden yang berusia $<40$ tahun. Kantachuvessiri et al (2005) bahwa kecenderungan obesitas yang dialami oleh seseorang yang berusia lebih tua yaitu pada usia 40-59 tahun diduga akibat lambatnya metabolisme, rendahnya aktivitas fisik, seringnya frekuensi mengonsumsi makanan dan kurangnya perhatian terhadap bentuk tubuhnya.

Uji analisis hubungan antara BMI dengan kadar gula darah puasa pada wanita dewasa, menunjukkan tidak ada hubungan yang signifikan antara BMI dengan kadar gula darah puasa pada wanita dewasa dengan $p$ vale >.05. Hasil penelitian ini didukung oleh Nasrul, Decroli, dan Putri (2015) dalam penelitiannya yang berjudul "Hubungan Derajat Obesitas dengan Kadar Gula Darah Puasa pada Masyarakat di Kelurahan Batung Taba dan Kelurahan Korong Gadang, Kota Padang" menyatakan tidak ada hubungan signifikan derajat obesitas dengan kadar gula darah puasa karena kadar gula darah puasa pada setiap individu dengan obesitas dapat dipengaruhi oleh beberapa faktor lainnya seperti pola makan, aktifitas fisik dan juga faktor 
genetik. Menurut penelitian Arif. Ernalia, dan Rosdiana (2014) dalam penelitiannya "Hubungan Indeks Massa Tubuh Dengan Kadar Gula Darah Puasa Pada Pegawai Sekretariat Daerah Provinsi Riau" menyatakan tidak terdapat hubungan yang bermakna antara indeks massa tubuh dengan kadar gula darah puasa. Keterbatasan jumlah responden bisa juga memengaruhi hasil penelitian ini, pada penelitian ini jumlah sampel minimal yang dibutuhkan sudah terpenuhi akan tetapi untuk mendapatkan hasil yang lebih spesifik dibutuhkan jumlah sampel yang lebih banyak sehingga faktor kesalahannya menjadi lebih kecil. Penelitian yang dilakukan oleh Fitrania disimpulkan bahwa hiperglikemia lebih banyak terdapat pada usia di atas 45 tahun dibandingkan usia 45 tahun ke bawah. Hal ini disebabkan pada usia muda metabolisme karbohidrat dan fungsi organ baik. Salah satu faktor yang berhubungan dengan meningkatnya gula darah yaitu aktivitas fisik. Menurut Anani dkk dalam penelitiannya menyatakan aktivitas fisik sangat berpengaruh meningkatkan sensitivitas pada insulin. Berdasarkan hasil penelitian yang ada BMI mengalami peningkatan tetapi gula darah dalam batas normal. Hal ini mungkin disebabkan karena responden merupakan penduduk pedesaan yang belum terlalu terpapar banyak dengan fast food seperti di kota-kota besar. Faktor lainnya juga yaitu responden rutin dalam menjalankan aktivitas sehari-hari seperti berkebun dan beternak.

Hasil penelitian ini berbeda dengan penelitian yang dilakukan oleh Priasmara, (2015). Dengan judul "Hubungan indeks masa tubuh dengan kadar gula darah pada lansia di kota semarang". Penelitian tersebut dilakukan terhadap 12 subject lansia dengan usia 60-74 tahun gula darah diperoleh dengan menggunakan uji strip gula darah. Dimana penelitian tersebut menyimpulkan bahwa ada hubungan yang signifikan antara gula darah dengan indeks masa tubuh pada lansia. Perubahan fisiologis yang terjadi pada lansia selain karena faktor proses penuaan itu sendiri, faktor lain yang dapat meningkatkan kadar gula darah pada lansia yaitu penurunan fungsi sel (degenerasi sel) yang mengakibatkan terjadinya peningkatan resistensi insulin Gangguan tersebut disebabkan karena melemahnya semua fungsi organ tubuh termasuk sel pankreas yang bertugas menghasilkan insulin. Sel pankreas dapat mengalami degredasi yang menyebabkan hormon insulin yang dihasilkan terlalu sedikit, sehingga kadar gula darah menjadi tinggi (Slamet, 2006), dan produksi hormon kortisol oleh kelenjar adrenal yang memberikan efek stress berlebih yang mempengaruhi perubahan pada lansia dan dapat meningkatkan tekanan darah dan kadar gula darah (Florencia, 2015). Faktor lainnya karena banyak mengkonsumsi makanan yang mengandung gula, kurang tidur, merokok, faktor keturunan, dan kurangnya aktifitas fisik. Tetapi faktor yang paling dominan mempengaruhi kadar gula darah tinggi yaitu kurangnya aktifitas fisik (Natalia, 2013).

Berdasarkan hasil penelitian yang di lakukan pada 45 responden ditemukan mayoritas gula darah puasa responden dalam batas normal sebanyak 41 orang dengan persentase $(91,1 \%)$. Gula darah merupakan istilah kesehatan yang menunjuk kepada kandungan gula dalam darah, sehingga beresiko terjadinya pradiabetes. Sementara itu pradiebetes merupakan kondisi dimana kadar gula dalam darah lebih tinggi dari batas normal. Bila tidak ditangani dengan baik, kondisi pradiabetes bisa berkembang menjadi diabetes Sedangkan menurut peneliti pilar utama dalam pengendalian obesitas dan kadar gula darah adalah edukasi atau penyuluhan, tapi pemahaman serta perilaku belum tentu benar serta tepat. Seperti penyuluhan tentang pola makan, pola makan yang tidak seimbang kadar gizinya akan berdampak pada metabolisme tubuh.

Tingkat aktivitas fisik juga berhubungan dengan status pekerjaan dan tingkat pendidikan responden. Seseorang yang bekerja cenderung mempunyai tingkat aktivitas fisik lebih tinggi. Pendidikan dapat mempengaruhi belajar, semakin tinggi pendidikan seseorang maka cenderung mudah mendapatkan informasi yang dapat mempengaruhi tingat pengetahuan. Seseorang dengan tingkat pendidikan tinggi cenderung lebih besar mengetahui beberapa hal yang dapat meningkatkan status kesehatannya seperti olahraga secara teratur, menjaga pola makan. Hasil penelitian menunjukkan sebagian besar responden memiliki tingkat pendidikan akhir SD dan SMP sehingga dapat diketahui bahwa karakteristik responden beresiko untuk terjadinya obesitas.

\section{Kesimpulan}

Dari hasil penelitian ditemukan bahwa sebanyak 42,2 \% (19 responden) wanita dewasa di RW 12 Desa Cihanjuang Rahayu memiliki status BMI tergolong Overwight atau gemuk dan $31,1 \%$ (14 responden) memiliki status BMI tergolong Obesitas. Untuk kadar gula darah puasanya didapati 91,1\% (41 responden) dalam batas normal,dan yang termasuk tinggi kadar gula darah puasanya hanya 4,4\% (2 responden). Pada penelitian ini dapat disimpulkan bahwa tidak ada hubungan yang bermakna antara BMI dengan kadar gula darah puasa $(\mathrm{p}=0,833)$ pada wanita dewasa di RW 12 Desa Cihanjuang Rahayu.

\section{Saran}


Penelitian lebih lanjut perlu dilakukan dengan rentang usia yang lebih panjang serta melibatkan kedua jenis kelamin serta analisis terhadap aktivitas hidup sehari-hari, sehingga dapat memberikan gambaran yang menyeluruh.

\section{Daftar Pustaka}

1. Arismunandar Roby. (2015). The Relations between obesity and ostheoarthritis knee in elderly patients. J Majority, Volume 4 Nomor 5 , Februari 2015.

2. Christina D, Sartika RA. (dikutip 3 Desember 2011). Obesitas pada pekerja minyak dan gas. Departemen gizi kesehatan masyarakat fakultas kesehatan masyarakat Universitas Indonesia. Available from: http://jurnalkesmas.ui.ac.id/index.p hp/kesmas/article/view/100/101

3. Guyton, Arthur, Hall 2007. Buku Ajar Fisiologi Kedokteran. Edisi 9. Jakarta : EGC

4. Hamel, R., Kepel, B., \& Dalawa N.F. (2013). Hubungan Antara Status Gizi Dengan Kadar Gula Darah Puasa Pada Masyarakat Kelurahan Bahu Kecamatan Malalayang Manado. ejournal keperawatan (e-Kp) Volume 1. Nomor 1. Agustus

5. Hamid, S., \& Trisna, I. (2009). Faktor-faktor yang berhubungan dengan obesitas sentral pada wanita dewasa (30-50 tahun) di Kecamatan Lubuk Sikaping Tahun 2008. Jurnal Kesehatan Masyarakat, Volume 3 Nomor 2, September 2009.

6. Hardinsyah, Yasmin, G., Yuliana, I., \& Diana, R. (2013). Faktor resiko kegemukan pada wanita dewasa Indonesia. JGP, Volume 8, Nomor 1, Maret.

7. Kaligis, M.H.S., Purwanto, S.D., Lestari, D.D. (2013). Gambaran Kadar Glukosa Darah Puasa Pada Mahasiswa Angkatan 2011 Fakultas Kedokteran Universitas Sam Ratulangi Dengan Indeks Massa Tubuh 18,5-22,9 kg/m . Jurnal $e$ Biomedik (eBM), Volume 1, Nomor 2, hlm. 991996.

8. Kantachuvessiri, A., Sirivichayakul, C., Kaewkungwal, J., Tungtrongchitr, R., \& Lotrakul, M. (dikutip 4 Juli 2005) Factors associated with obesity among workers in a metropolitan waterworks authority. Southeast Asian J Trop Med Public Health ; 36:1057-65. Available from: http://www.thaiscience.info/journals/Article/Factor

\section{s\%20associated\%20with\%20obesity\%20among\% 20workers\%20in\%20a\%20metropolitan\%20water works\%20authoriy.pdf}

9. Liberty, A.I. (2016). Hubungan Obesitas dengan Kejadian Prediabetes pada Wanita Usia Produktif. Jurnal Kedokteran Dan Kesehatan. Volume 3, N0. 2, April: 108-113.

10. Malinti, E., \& Elon, Y. (2019). Hubungan asupan natrium, kalium; indeks masa tubuh, lingkar pinggang dengan tekanan darah pria dewasa muda. Riset Informasi Kesehatan, 8(1), 1-8. doi:10.30644/rik.v8i1.213

11. Martini, S., \& Hi'imiyah, A.D. (2013). Hubungan antara Obesitas dengan Osteoporosis Studi di Rumah Sakit Husada Utama Surabaya. Jurnal Berkala Epidemiologi, Vol. 1, No. 2 September : 172-181.

12. Martini, S., \& Septyaningrum, N . (2014). Lingkar Perut Mempunyai Hubungan Paling Kuat dengan Kadar Gula Darah. Jurnal Berkala Epidemiologi, Volume 2 Nomor 1, Januari 2014, hlm. 48-58

13. Maryani, H., Roosihermiatie, B., \& Handajani, A. (2010). Faktor-Faktor Yang Berhubungan Dengan Pola Kematian Pada Penyakit Degeneratif Di Indonesia. Buletin Penelitian Sistem Kesehatan. Vol. 13 No. 1 Januari : 42-53.

14. Mayulu, N., Pangemanan, D., \& Betteng, R. (2014). Analisis Faktor Resiko Penyebab Terjadinya Diabetes Melitus Tipe 2 Pada Wanita Usia Produktif Dipuskesmas Wawonasa. Jurnal $e$ Biomedik (eBM), Volume 2, Nomor 2, Juli.

15. Nasrul, E., Decroli, E., \& Putri, Y.F. (2015). Hubungan Derajat Obesitas dengan Kadar Gula Darah Puasa pada Masyarakat di Kelurahan Batung Taba dan Kelurahan Korong Gadang, Kota Padang, Jurnal Kesehatan Andalas ; 4(3), Available from : http://jurnal.fk.unand.ac.id

16. Novriani, H., Susilawati D.M., \& Ghani, L. (2016). Faktor resiko dominan penyakit jantung koroner di Indonesia. Buletin Penelitian Kesehatan, Vol. 44, No. 3, September : $153-164$

17. Oktaviani, S. (2018). Hubungan Kadar Gula Darah Terhadap tekanan darah pada lansia di Desa Junrejo Kota Batu. 
18. Purwandari, H. (2014) Hubungan obesitas dengan kadar gula darah pada karyawan di rs tingkat IV Madiun. Jurnal, Volume 1 Nomor 25 , Desember.

19. Priasmara, Y.D. (2015) Hubungan Indeks massa tubuh dengan kadar gula darah pada lansia di kota semarang tahun 2014.

20. Ramadhan, R., Wilya, V., \& Nur, A. (2016). Kebiasaan Aktivitas Fisik Pasien Diabetes Mellitus Terhadap Kadar Gula Darah Di Rumah Sakit Umum dr. Fauziah Bireun. Kebiasaan Aktivitas Fisik Pasien Diabetes Mellitus... SEL Vol. 3 No. 2 November 2016: 41-48

21. Riset Kesehatan Dasar. Laporan Nasional. 2018. Hasil Utama RISKESDAS. 2018.

22. Rosdiana, D., Ernalia, Y., \& Arif, M. (2014). Hubungan Indeks Massa Tubuh Dengan Kadar Gula Darah Puasa Pada Pegawai Sekretariat Daerah Provinsi Riau. JOM, VOL.1, NO.2.

23. Wicaksono, P.R. (2011). Faktor-faktor yang berhubungan dengan kejadian diabetes mellitus tipe 2 (studi kasus di poliklinik penyakit dalam rumah sakit Dr. Kariadi).

24. World Health Organization. (diunduh Januari 2013). Obesity and overweight 2012. Tersedia dari: URL: HYPERLINK http://www.who.int/en/ 